\title{
幼児の逆転移行学習と抽象能力
}

\author{
奈良教育大学 \\ 杉村健
}

Kendler and Kendler (1962) は逆転移行と非逆転移 行の比較に関する発達的研究の成果にもとづいて, S-r$\mathrm{s}-\mathrm{R}$ の図式をとり入れた媒介 S-R 説を提呾した。この理 論の特徵は，(1)媒介過程が外的S-Rの過程上同じ法則に 従うこと，拉よび(2媒介過程は内的な言語反応であって 発達水準に関係していると考えられていることである。 後者の証拠として彼らは，ネズミや年少児では非逆転移 行が逆転移行よりも速く, 年長児や成人では逆転移行の 方が有利であることをあげている。 Kendler and Kendler(1962)によれば，年少児は 1 単位のS-R説(Spence, 1936）にあてはまる非媒介者であって，言語的媒介が利 用できないが，年長児は媒介的 $\mathrm{S}-\mathrm{R}$ 説にあてはまるよ な媒介者であって，言語的媒介を利用することができる という。また，言語的媒介を有する年長児において逆転 移行が非逆転移行より速いのは, 逆転移行では先行学習 で形成された適切次元に対する内的な言語命名がそのま ま利用できるのに対して，非逆転移行ではその言語命名 を消去して新しいものを作らなくてはならないからであ るといら。

ところで，このような言語的要因の役割を実験的に評 価しようと試みた従来の研究においては, 先行弁別の刺 激に対する外的な言語反応（命名）が媒介過程の機能を 促進させると考えられている。したがって，弁別刺激に 対する言語命名は逆転移行を促進するか, あるい㦏択 移行問題において逆転移行者を増加させることを予言す る。たとえば, Kendler (1964) と杉村 (1967) は, 言語 命名によって選択移行問題における逆転移行者が増加す ることを示し，予想を確かめた。しかしながら， Blank (1966), Kendler (1960)およびMorse and Shepp(1967) においては，言語命名によって逆転移行が促進されると いう結果が得られず，また， Mumbauer and Odom (1967)は部分的に予想と一致する結果をえた。弁別問題 や実験手続きなどの点で異なるから厳密な比較はできな いが, 従来の研究をまとめてみると, 群内比較である選 択移行問題を用いたときには予想された言語命名の効果
があり，群間比較である弁別移行問題ではそれがえられ にくいといえよう。いずれにせよ，上に述べた研究はど れも, 先行弁別の刺激に対して言語命名を行なわせるこ とによって，媒介過程における言語的要因の役割を評価 しているのである。

そのようなやり方に対して Cobb and Price (1966) は，弁別学習中ではなくて，それに先立って独立に訓練 した刺激に対する言語命名が，弁別移行にいかなる効果 をもつかを検討した。その結果は，多分訓練量が少ない ために, 言語命名の予想された効果を示さなかったが, 彼らが用いた方法は従来のものとは異なって, 弁別学習 とは独立に言語的要因が操作されている点で注目に值す る。これに関連して, Beilin and Gillman (1967) は序 数と基数についての数概念を独立に測定し, それと数弁 別の逆転との関係を調べ，また，Johnson and White （1967）は大きさまたは明暗次元を概念化する能力が逆転 移行の速さと関係があることを示した。

媒介過程と実験者が操作しうる独立変数との関係を追 求しょうとする試みは, 実験的には最近始められたばか りであるが，理論的にはすでに Morrisett (Kendler, 1963）によって示唆されている。Kendler (1963) が行 なった媒介反応の発達についての講演に対する個人討論 において, Morrisett は11仲介変数としての媒介過程と 観察可能な独立および従属変数との関係が特殊化されて いない，(2)生活年令は心理学的には十分な先行条件とは なりえないと主張して，Kendler たちの媒介反応説を 批判した。そして, 独立変数としては言語の流暢さ, 語 い，および知能などが用いられることを示唆した。

本実験の目的は, 幼児の言語的な抽象能力と逆転移行 の速さの関係を吟味することである。

Kendler and Kendler (1962) は媒介過程の形成と利 用は年令と言語能力に関係するという。そして彼らの図 式に抢ける媒介過程（r-s）は“色”“大きさ”あるいは “形”であるとされている。これは赤い刺激と青い刺激 から色が抽象され, あるいは大きい刺激と小さい刺激か 
ら大きさが抽象される過程と対応しているであろう。し たがって, 同一年令の者であっても, そのような抽象能 力が高いほど，媒介過程を利用しやすいと考えられる。 本実験においては，2つの対象に共通する上位極念を求 める問題を与えて子供の抽象能力を調心，その高い者と 低い者に対して大きさと明暗の 2 次元からなる弁別問題 を学習させた。本実験で吟味する仮説は次のとおりであ る。抽象能力の高い者は低い者にくらべて媒介過程を利 用しやすいので，逆転移行学習がより速くなされるであ ろう。

\section{方 法}

被験者 被験者は奈良市内にある 2 つ幼稚園の男子 88名, 女子 72 名, 合計 160 名であった。その年令は 4 才 8 ケ月から 6 才 2 ケ月の間にあり, 平均 5 才 7 ケ月であ った。全被験者に抽象語検査を与え，その結果にもとう いて成績のよい方から 40 名と悪い方から 40 名の者を選 び，約 1 カ月後に弁別問題を与えた。上位群の平均年令 は 5 才 8 ケ月，下位位群のそれは 5 才 6 ケ月であった。

抽象語検查 市販されている若干の知能検查を参考に して, Table 1 に示したよらな 20 個の問題を作った。 Table 1 の最右列にはそれぞれの項目の正答が示されて

Table 1

抽象語検査の項目と得点になる回答(正答)

\begin{tabular}{|c|c|c|c|c|c|c|}
\hline & & 項 & & 目 & & 正 答 \\
\hline 1 & す & ず & め & は & と & 鳥 \\
\hline 2 & あ & さが & お招 & ひまわ & y & 花 \\
\hline 3 & ま & & つ & す & ぎ & 木 \\
\hline .4 & $w$ & & ぬ & 水 & $こ$ & 動 物 \\
\hline 5 & $こ$ & & い & 子 & な & 魚 \\
\hline 6 & $\eta$ & L & ご & み か & L & 果 物 \\
\hline 7 & だ & いこ & ん & にんじ & ん & 野 菜 \\
\hline 8 & 子 & & 放 & じどうし & や & 乗 物 \\
\hline 9 & $ヒ^{\circ}$ & ア & ノ & $M-モ=$ & カ & 楽 器 \\
\hline 10 & $\S$ & ル & ク & $\forall=z-$ & ス & 飲 物 \\
\hline 11 & つ & ば & め & か ら & す & 鳥 \\
\hline 12 & す & み & れ & たんぽ & ぽ & 花 \\
\hline 13 & ポ & $7^{\circ}$ & ラ & も み & じ & 木 \\
\hline 14 & ぞ & & $う$ & ライオ & ン & 動 物 \\
\hline 15 & め & だ & か & き んぎ & よ & 魚 \\
\hline 16 & バ & ナ & ナ & ぶ ど & 5 & 果 物 \\
\hline 17 & キ & ヤ べ & ツ & ほうれんそ & 5 & 野 菜 \\
\hline 18 & き & し & p & ひこ $こ$ & き & 乗 物 \\
\hline 19 & 才 & ル ガ & ン & バイオリ & ン & 楽 器 \\
\hline 20 & ב & - ヒ & - & 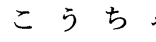 & p & 飲 物 \\
\hline
\end{tabular}

いる。これ以外にも正答とされる回答がありらるが，本 実験においては表に示された回答のみを正答として, 各 1 点ずつを与えた。したがって検查の得点は 0 点から 20 点まで分布する。

弁別問題 2 次元 2 值の弁別問題が用いられた。弁別 刺激は白と黒のつや紙で作られた， 1 辺が $7.5 \mathrm{~cm}$ と 2.5 $\mathrm{cm}$ の正方形である。それらは大きさと明暗がそれぞれ 異なるように組合わされ， $18 \times 12.5 \mathrm{~cm}$ の白い画用紙に 左右に並べて貼りつけられた。かくして，大きい白と小 さい黒および大きい黒と小さい白の 2 対と, それらと左 右の位置が逆になっている 2 対の合計 4 対が作られた。 各対は10枚ずつ合計40枚の刺激カードが用意され，これ らのカードは同じものが 2 回続かないこと, 各カードが 20 試行の中に同数ずつ呈示されることを条件として，ほ ぼランダムに配列された。

手続き 被験者は所属する幼稚園の個室で個別的に実 験を受けた。机をはさんで実験者と向かい合ってすわる と, 氏名をきかれたり短かい会話をしたあとで，抽象語 検查が次の教示によって与えられた。

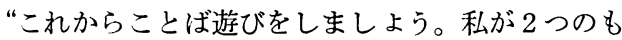
のの名前をいいますから，その 2 つのもの゙゙とんなと ころで一番よく似ているかを考えてください。たとえ ば，スカートとブラウスはどちらも服ですね。では， すずめとはとは両方とも何ですか”

この教示につゔいて，あさがおとひまわりは両方とも 何ですか，まつとすぎは両方とも何ですかというよう に，20個の項目が与えられた。な掞，やり方がよく理解 できない者に対しては，教示をくり返したり，別の例に よって理解させてから検査を行なった。また，無答の場 合にはもう一度その項目をくり返して質問したが, 誤答 の場合に泟答のときと同様に，実験者はうなずきなが ら “はい”といっ.て回答を記入するだけで，答えが正し いか誤りかは教えなかった。

抽象語検查の実施後約 1 力月たってから，先に述べた 80名の者に対して弁別問題を訓練した。刺激カードを呈 示しながら，次の教示を与えた。

“これからカード遊びをしましょう。このカードに は 2 つの絵が貼ってあります。このうちどちらかがい つも“あたり”と決めてありますので，“あたり”と 思う方を指さしてください。はじめはどちらが当たり か分かりませんが，やっているらちにだんだん分かっ てきますから，できるだけ速く，続けて何回も当てて ください。あなたの指さしたのが当たっていれば“ “あ たり”はずれていれば“はずれ”といいますから，い つも“あたり”といわれるように頑張ってください” 
教示に続いて, 先行弁別問題が開始された。そのさ い, 抽象語検査における上位群と下位群（それぞれ40名 ずつ）の被験者の 4 分の 1 (10名) ずつが, 大, 小, 白,

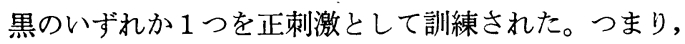
被験者の半分は大きさを適切次元として学習し, 残りの 半分は明暗を適切次元として学習したことになる。刺激 カードは被験者の反応速度に応じ, 実験者の手によって 1 枚ずつ呈示された。先行弁別の学習基準は10回中 9 回 正反応であった。40試行までにこの基準に達しないとき には，実験者が正刺激を指さし“これが当たりですよ” といって教えた。この特殊な訓練によって, すべての被 験者は学習基淮に達することができた。

先行弁別の学習基準に達すると, 新たな教示を与えた り，試行間を区切ったりすることなく，これまでと同様 に刺激カードを続けて呈示しながら, 逆転移行が行なわ れた。すなわち, 正刺激が大 $\rightarrow$ 小, 小 $\rightarrow$ 大, 白 $\rightarrow$ 黑, 黒 ＼cjkstart白と同じ次元内で逆転させられた。この学習基準も 10 回中 9 回正答であり，40試行までにこの基準に達しない ときは実験を中止した。なお，用いられた刺激カードは 40枚であるので, 弁別および逆転を通じて40試行以上必 要としたときは, も5一度第 1 枚目のカードからくり返 し呈示した。

\section{結果}

抽象語検査 160 名についての抽象語検査の結果は, 得点の平均が 8.7 , 標準偏差は 5.8 , 範囲は 0 18であ った。Table 2 は上位群と下位群について, 弁別学習に おける適切次元ごとに, 抽象語検查の得点の平均とその 範囲を示したものである。この表は, 当然のことなが ら, 上位群と下位群では抽象能力がまったく異なること を示している。両群の年令はわずか 2 ケ月のちがいであ るが, これは統計的に有意であった $(t=2.270, d f=$ $78, p<.05)$. しかしながら，160 名全員について年令 （月）と抽象語検查の得点の間の相関係数を求めてみる と, $r=-0.14$ となり, 有意ではないが負の相関が得ら れた。これは上位群の方が年令が高いといら結果と矛盾 するようであるが，相関係数の場合には中間の者 80 名の

\section{Table 2}

上位群亡下位群における抽象語検查の平均と範囲

\begin{tabular}{|c|c|c|c|c|c|}
\hline & \multirow{2}{*}{$\begin{array}{l}\text { 人 } \\
\text { 数 }\end{array}$} & \multirow{2}{*}{ 年 } & \multicolumn{3}{|c|}{ 弁別問題の適切次元 } \\
\hline & & & 大きさ & 明 & 暗 \\
\hline & 40 & 67 & $14.40(12-18)$ & 15.10 & $(2-18)$ \\
\hline 下位群 & 40 & 69 & $2.45(0-6)$ & 2.55 & $0-5)$ \\
\hline
\end{tabular}

資料がはいっているのに対して，平均の比較ではそれが はいっていないことによるのかもしれない。そこで，全 体的にみるならばこの範囲の年令（56ケ月～74力月）で は，この種の抽象能力と年令との間にはあまり関係がな いとみなしてよいであろう。

先行弁別 まず，先行弁別問題における正刺激によっ て学習の速さが異なるかどうかを調べた。その結果，正 刺激が大, 小, 白, 黒のそれぞれについて, 学習に要し た試行数 (誤数) の $\sqrt{\mathrm{X}+0.5}$ 変換值による平均は, 上位群と下位群をこみにしたとき，2.00(1.54), 2.68 (2.13)，2.60(2.13), および 2.74(2.03) であって, 大 を正刺激としたときに学習が速い傾向があった。しか し，分散分析の結果は有意差がなかったので（試行数で $F<1$, 誤数で $F=1.610)$, 以後の分析に㧍いては, 大 上小および白上黒をそれぞれこみにして，大きさ次元お よび明暗次元として処理する。

Table 3 は先行弁別の学習基準に達するのに要した試 行数（誤数）の平均を示したものである。2(群) $\times 2$ (次 元）の分散分析は, 試行数と誤数のいずれにおいても主 効果, 交互作用ともに有意でなかった。それ功え, 先行 弁別に関しては各下位群の学習能力がほぼ等しいとみな された。なお, 分散分析の結果は, 試行数の群差が $F(1,76)=2.198, p>.10$ で, その他は誤数の場合も含 めてすべて $F<1$ であった。

\section{Table 3}

先行弁別における学習基準までの試行数 (誤数)の平均 $(\sqrt{\mathrm{X}+0.5}$ 変換による)

\begin{tabular}{c|ccc}
\hline & $\begin{array}{c}\text { 適 切 } \\
\text { 大きさ }\end{array}$ & 次 元 & 平 均 \\
& 大暗 & \\
\hline 上位群 & $2.01(1.77)$ & $2.41(1.89)$ & $2.21(1.83)$ \\
下位群 & $2.67(1.90)$ & $2.93(2.27)$ & $2.80(2.08)$ \\
\hline 平 均 & $2.34(1.83)$ & $2.67(2.08)$ & \\
\hline
\end{tabular}

逆転移行 Table 4 は逆転移行における学習基準まで に要した試行数（誤数）の平均を示したものである。 $2 \times 2$ の分散分析の結果は次のと抢りであった。(a)試行 数については群差が $F(1,76)=5.986$, 群上次元の交互 作用が。 $F(1,76)=4.738$ で，ともに $5 \%$ 水準で有意であ った。そこで，分散分析の誤差項 (1.545) を用いて単純 効果の検定をしたところ, 明暗次元においてのみ群差が 有意であった $(t=3.256)$. (b)誤数においても群差が $F(1,76)=5.000$ で $5 \%$ 水準で有意になったが，交互作 用はわずかに有意水準に達しなかった $(F=3.888)$ 。ち なみに, 誤差項 $(0.714)$ を用いて単純効果を調べてみる 
と, 試行数と同様に明暗次元においてのみ群差が有意で あった $(t=2.659) 。$

\section{Table 4}

逆転移行における学習基準までの試行数 (誤数) の平均 $(\sqrt{\mathrm{X}+0.5}$ 変換による)

\begin{tabular}{|c|c|c|c|}
\hline & 適 切 & 次 元 & \multirow{2}{*}{ 平 均 } \\
\hline & 大きさ & 明 暗 & \\
\hline 上位群 & $2.46(2.05)$ & $1.85(1.76)$ & $2.15(1.86)$ \\
\hline 下位群 & $2.53(2.10)$ & $3.13(2.47)$ & $2.83(2.28)$ \\
\hline 平 均 & $2.49(2.07)$ & $2.49(2.07)$ & \\
\hline
\end{tabular}

\section{考察}

本実験の主な結果は，(a)抽象能力が高い者は低い者に くらべて逆転移行が速い，(b)抽象能力の相違は，大きさ 次元よりも明暗次元における逆転移行の成績に反映され ているということであった。

結果(a)は本実験の仮説を支持し，これは媒介的 $S-R$ 説 (Kendler \& Kendler, 1962) の枠組みに扔いて解釈さ れうる。すなわち，抽象能力が高い者は弁別学習のさい に刺激次元に対寸る内的言語反応を媒介として利用しや すいので，逆転移行がより速くなされる。本実験で用い た抽象語検査は， 2 物間に共通な特徵ない儿上位概念を 発見する能力を測定している。一方, 媒介反応は 2 刺激 間に共通な特徴すなわち刺激次元に対寸る内的言語反応 であるとみなされているが，しかし，それは㨁接観察で きないものと考えられている。そこで, 本実験で測定し た抽象能力は, 仲介変数としての媒介過程に対応する観 察可能な独立変数であるとみなせるであろう。それゅ え, 生活年令以外の言語能力の上うな変数を独立に操作 したときにも，媒介説を支持する証拠がえられたのであ る。

結果(b)は，本実験の仮説が主として明暗が適切次元の とき支持されていることを示している。これは，明暗次 元の弁別学習においては, 抽象能力の高い者之低い者と で媒介反応を利用する程度が異なるが，大きさ次元では それが異ならないこと，つまり，媒介の利用は弁別学習 における適切次元と被験者の能力に依存していることを 示唆する。

上位群の平均年令はわずかに 2 力月ではあるが下位群 のそれにくらべて有意に高かった。このことから，本実 験の結果は抽象能力の差によって生じたものではなく, 年令差によって説明できると批判されるかもしれない。 しかし，Kendler and Kendler（1962）の発達仮説は
5 才 7 カ月と 5 才 9 カ月を区別するほど精確ではなく, また，Table 2 からもわかるように，年令差よりも抽象 能力における差の方がはるかに大きいことからみて，年 令差による説明には賛成しがたい。

\section{要約}

本実験の目的は，幼児における逆転移行学習の速さが 抽象能力と正の関係を示すといら仮説を検証することで ある。この仮説は, Kendler and Kendler (1962)の言 語的媒介反応説から演繹されたものである。

160 名の幼児がそれぞれ 2 つの対象からなる20項目の 抽象検査を与えられた。被験者は，たとえば “すずめと はとに共通な特徴はなんですか”というように，2つの 対象に共通する抽象語を推測するようにいわれた。この 検査にもとづいて，40名が得点の低い方から，40名が得 点の高い方から選択され，そしてその者に対して弁別と 逆転を与えた。2 次元（大きさと明暗）の弁別問題が用 いられた。それは大きい黑と小さい白の正方形の対と大 きい白と小さい黒の正方形の対からなっている。被験者

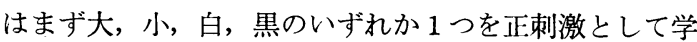
習した。それが完成すると教示を加えたり中断すること なしに, 逆転が与えられた。弁別と逆転の学習基淮は 10 回中 9 回正答であった。

主な結果は次のとおりであった。(a)高い抽象能力をも つ者と低い抽象能力をもつ者の間に, 弁別の成績に有意 な差がなかった。(b)明暗次元が適切なとき高い抽象能力 をもつ者は低い抽象能力をもつ者よりも逆転移行問題を 速く学習した。しかし，大きさ次元が適切なときは両者 の間に有意差がなかった。以上の結果を，Kendler たち の言語媒介モデルに関連して考察した。

〈附記〉資料の蒐集にあたり奈良教育大学福井陽子さ 几の協力をえた。また，実験にあたり奈良市立佐保幼 稚園と東大寺幼稚園の協力をえた。心から感謝します。

\section{文献}

Beilin, H., \& Gillman, I. S. 1967 Number language and number reversal learning. J. exp. Child Psy. chol., 5, 263-277.

Cobb, N. J., \& Price, L. E. 1966 Reversal and nonreversal shift learning in children as a function of two types of pretraining. Psychol. Rep., 19, $1003-1010$

Johnson, P. J., \& White, R. M. 1967 Concept of dimensionality and reversal shift performance in children. J. exp. Child Psychol., 5, 223-227. 
Kendler, H. H., \& Kendler, T. S. 1962 Vertical and horizontal processes in problem solving. Psychol. Rev., 69,1-16.

Kendler, T. S. 1963 Development of mediating responses in children. In J. C. Wright \& J. Kagan (Eds.), Basic congnitive processes in children, Monogr. Soc. Res. Child Develpm., 28, No. 2 (Serial No. 86), $33-52$.

Kendler, T. S. 1964 Verbalization and optional reversal shifts among kindergarten children. $J$. verb. Learn. verb, Behav., 3, 428-436.

Kendler, T. S., Kendler, H. H., \& Wells, D. 1960 Reversal and nonreversal shifts in nursery school children. J. comp. physiol. Psychol., 53, 83-88.

Morse, P. A., \& Shepp, B. E. 1967 The effect of overt verbalization and overtraining on dimensional shifts. In B. E. Shepp, Studies on discriminative learning and transfer in normal and retarded children. Progress Report, No.1,96121.

Mumbauer, C. C., \& Odom, R. D. 1967 Variables affecting the performance of preschool children in intradimensional, reversal, and extradimensional shifts. J. exp. Psychol., 75, 180-187.

Spence, K. W. 1936 The nature of discrimination learning in animals. Psychol. Rev., 43, 427-449. 杉村 健 1967 幼児の選択移行におよぼす言語反応と 過㮃訓練の効果 心研, $38,265-273$.

(1968年 8 月 5 日原稿受付)

\title{
ABSTRACT
}

\section{REVERSAL SHIFT LEARNING AND ABSTRACTION ABILITY IN KINDERGARTEN CHILDREN}

\author{
by \\ Takeshi Sugimura \\ Nara University of Education
}

The purpose of the present experiment was to test the hypothesis that ease of reversal shift learning in kindergarten children is positively related to the S's abstraction ability. This hypothesis was deduced from the verbal mediating response theory (Kendler \& Kendler, 1962).

160 kindergarten Ss were given an abstract word test consisting of 20 items of two objects in each. The Ss were required to guess an abstract word common to the two objects, e. g., "What is the common property to a sparrow and a swallow?" Based on the test, 40 Ss were selected from the upper end of the scores and 40 Ss were from the lower end, and then they were trained on a discrimination and a reversal. A two-dimensional, size and brightness, discrimination task was used, which consisted of two pairs of squares, i. e., large black and small white, and large white and small black.
The Ss first learned the discrimination task with one of the following as the positive stimulus: large, small, white, and black. Upon completing the discrimination, Ss were given a reversal shift without further instructions or any interruption. The learning criterion in the discrimination and reversal was nine out of 10 succssive correct responses.

The main results were as follows: (a) No significant difference in the discrimination performance was found between the high-abstraction ability (HA) Ss and low-abstraction ability (LA) Ss, and (b) the HA Ss learned faster the reversal shift task than the LA Ss when the brightness dimension was relevant, but no significant difference in the reversal performance was found when the size dimension was relevant. The findings supported the present hypothesis, and were discussed with reference to the Kendlers' verbal mediational model. 